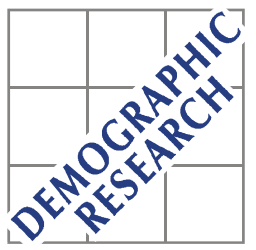

Demographic Research a free, expedited, online journal

of peer-reviewed research and commentary in the population sciences published by the Max Planck Institute for Demographic Research

Konrad-Zuse Str. 1, D-18057 Rostock · GERMANY

www.demographic-research.org

DEMOGRAPHIC RESEARCH

VOLUME 24, ARTICLE 8 PAGES 201-216

PUBLISHED 02 FEBRUARY 2011

http://www.demographic-research.org/Volumes/Vol24/8/

DOI: $10.4054 /$ DemRes.2011.24.8

Reflexion

\title{
Should governments in Europe be more aggressive in pushing for gender equality to raise fertility? The first "NO"
}

\section{Dimiter Philipov}

This publication is part of the Special Collection "Rostock debate on demographic change”, organized by Guest Editor Laura Bernardi.

(C) 2011 Dimiter Philipov.

This open-access work is published under the terms of the Creative Commons Attribution NonCommercial License 2.0 Germany, which permits use, reproduction \& distribution in any medium for non-commercial purposes, provided the original author(s) and source are given credit.

See http:// creativecommons.org/licenses/by-nc/2.0/de/ 


\section{Table of Contents}

1 Introduction $\quad 202$

2 The intersection between family policies and gender equality 202 policies

3 The dual-earner / dual-career model as an optimal solution 204

4 Empirical observations 205

5 Objections 207

$6 \quad$ Summary and conclusions 213

$\begin{array}{ll}\text { References } & 214\end{array}$ 


\title{
Should governments in Europe be more aggressive in pushing for gender equality to raise fertility? The first "NO" 1
}

\author{
Dimiter Philipov ${ }^{2}$
}

\begin{abstract}
This paper takes the "no" side in the debate on the question posed in the title. The paper assumes that the dual-earner/dual-carer household model is the most likely aim of policies that push aggressively for gender equality in order to raise fertility. Five objections are discussed: the model does not necessarily lead to a fertility increase; aggressiveness will lead to an imbalance of labor supply and demand, and is likely to confront slowly changing cultural norms; similar policies will also confront the issue of innate gender differences; and country idiosyncrasies prevent the application of a unified policy approach. The paper briefly concludes that compatible gender-neutral family policies and fertility-neutral gender policies are likely to lead to an increase in fertility.
\end{abstract}

\footnotetext{
${ }^{1}$ This is the first of two "no" positions taken from the "Rostock Debate on Demographic Change" held at the Max Planck Institute for Demographic Research on 21 February 2006.

${ }^{2}$ Vienna Institute of Demography, Austrian Academy of Sciences. E-mail: dimiter.philipov@oeaw.ac.at
} 


\section{Introduction}

Many countries in Europe have considerable experience in the implementation of policies that aim to increase fertility, and of policies that seek to promote gender equality. Over the last two decades, these two policy fields have attracted interest among scientists and policy makers, particularly because gender issues are considered to be among the obstacles to having children. It is argued that the incompatibility of career and family for women is among the main reasons for contemporary low fertility. It is also argued that the effect of this incompatibility can be significantly reduced through a transition from the classical male breadwinner model to the dual-earner/dualcarer model.

In this paper, I first discuss a central intersection between gender equality policies and family policies (including policies which aim to increase fertility): namely, the reconciliation of work and family roles. Next, I raise several objections to the opinion that the dual-earner/dual-carer model is a convenient solution to the dilemma, and emphasize that governmental intervention can be of low efficiency. I conclude that an efficient increase in fertility can be achieved when family policies are gender-neutral, and when gender equality policies are fertility-neutral.

\section{The intersection between family policies and gender equality policies}

Pronatalistic family policies have dominated in the ex-socialist countries before the start of the transition (Debroy 1989). They were found to have a moderate effect on the level of fertility, in that, during the years after their implementation, births increased by around 10\% (Büttner and Lutz 1990, showed this for the GDR, Philipov 1993, for Bulgaria and Stloukal 1998, for Czechoslovakia). Family policies were also implemented in other European countries. Although their main aim is to support families, they have an indirect effect on fertility, since the main instruments of a family policy, such as child allowances and parental leaves, were also the main instruments in the pronatalistic policies (see, for example, Rønsen and Skrede 2008). ${ }^{3}$ In an international comparative framework, Gauthier and Hatzius (1997) found a moderate positive effect of family policies on fertility. Policies aiming at higher fertility have been long-standing in France, and their positive effect is well-known (Pailhé, Rossier, and Toulemon 2008). Also well-known are the positive effects on fertility of family

\footnotetext{
${ }^{3}$ For this reason, the differentiation between family policies and pro-natalistic policies is not of significance in this paper.
} 
policies implemented in social democratic welfare regimes in the Nordic countries (see Björklund 2006, and Andersson 2008 for Sweden, and Rønsen and Skrede 2008, for the Nordic countries). In general, family policies may bring about a moderately higher fertility level (Gauthier and Philipov 2008). A major problem with the implementation of family policies is that some of the key policy instruments, such as child allowances, are expensive, and a large number of European countries cannot afford their long-term implementation at levels that are commensurate with parental spending on child care and nurture (Gauthier 2007).

Gender equality has been the subject of extensive discussions about the achievement of human rights and contemporary democratic values, particularly where the rights of women are considered. The topic became "hot" during the 1960s, when it was acknowledged that gender discrimination was a fact in the societies of the time. The legal system underwent a corresponding adjustment; a well-known example is the "equal opportunities" act adopted in many European countries decades ago. When compared with society of the 1960s, equal opportunities were indeed achieved in many spheres of contemporary European societies. However, from the contemporary pointof-view, gender equality is still not satisfactory. In some spheres, such as in the labor market, gender inequality is apparent when practices, not laws, are considered. For example, pregnancy can be an obstacle to the employment of women in some countries, and the gender wage gap is persistent throughout Europe. The restriction of bad practices can be achieved with specific policies for the enhancement of gender equality. It has, however, been found to be more effective to consider and, if necessary, to introduce the gender equality issue in any legal act or social policy. The latter approach is known as gender mainstreaming, and it has been extensively advocated since the mid-1990s by international bodies such as the United Nations, The Council of Europe, the European Union (see for example the site of the Council of Europe: http://www.coe.int/T/E/Human_Rights/Equality/02._Gender_mainstreaming/ or the paper available at that site: Council of Europe 1998).

Mainstreaming gender as a constituent of contemporary policy making may have a variety of effects on fertility. For example, gender equality with respect to employment and payment of labor causes a rise in the opportunity costs of children for women, and, hence, following the economic theory of fertility (Becker 1991), will have a negative impact on fertility. Inversely, a decrease in uncertainty through higher security in the employment of pregnant women or of mothers exemplifies an effect that is likely to bring about a rise in fertility. The latter type of positive effect is a "by-product" of the relevant policy; i.e., an indirect policy effect. Our "no" does not relate to outcomes of gender-related policies that lead only indirectly to an increase in fertility. However, since a negative gender policy impact on births conflicts with family policies, these 
policies need adjustments to achieve inter-policy consistency. The latter topic has so far attracted relatively little attention among scientists and policy makers.

The conflict between work and family roles is an important intersection between family policies and gender equality policies. In families with children, it is known as the "work and nurture" dilemma. The conflict is particularly relevant to families with both spouses/partners present, because spouses have a wider range of opportunities for time allocation; i.e., for the distribution of the household chores. The latter distribution is an issue of gender equality. A successful solution to the conflict is one that gives more opportunities to women to participate in the labor market, while allowing them sufficient time for their children and families. The conflict has become more transparent over the last couple of decades, when ideational changes included an increase in the desire among women for autonomy, self-realization, and self-establishment (Lesthaeghe 1995). To this end, women increasingly prefer having a career to staying at home and doing the household chores. The conflict between work and family roles became the focus of both family and gender equality policies. Contemporary family policies include specific instruments designed to ease burdens on working parents, such as the promotion of paternity leave, even though in practice this form of leave has gained ground in relatively few countries up to now (see Figure 3 in Gauthier and Philipov 2008). Meanwhile, gender policies apply diverse instruments to promote the transition from the classical breadwinner model to the contemporary dual-earner/dual-carer model. I discuss these models in the next section.

\section{The dual-earner / dual-career model as an optimal solution}

Participation in labor and family roles take diverse forms when both spouses (or partners in a non-marital union) are present in the family. Two models encompass most of this diversity: the male breadwinner model and the dual-earner model (discussed by Lewis 1992, in the framework of gender regimes), which are outlined below.

A. The male breadwinner model. The man works full time and allocates little time to supporting household work, while the woman does not work for pay and takes over the household responsibilities. A specific version is the female breadwinner model in which the roles of the man and the woman are reversed; since this model is rare, I do not consider it in the present discussion.

B. The dual-earner model, in which both partners work. In one version of the model (The dual-earner/dual-carer model, woman full-time earner) both partners share equally paid work and work in the household. Another version is one in which the woman works part-time, and hence the partners share paid work and work in the household unequally (the dual-earner/dual-carer model, woman part-time earner). I 
discuss these models later. Yet another version of the dual-earner model is widely seen as supporting gender inequality: the dual-earner/woman-carer model, in which both partners engage in paid work, but it is the woman who takes over the bulk of the household work. I will not discuss this model because, regardless of its relevance to fertility, governments and society should do their best to discourage it as a source of contemporary gender inequality.

The male breadwinner model represents the traditional distribution of labor in the household. Recent decades have seen a transition from this model towards the dualearner model, as has been described and analyzed in a vast body of literature (see for example Lewis 2001, Pascal and Lewis 2004, Blossfeld and Drobnic 2001). The transition marked the emergence and rise of new models, such as the varieties of the dual-earner model specified above. Typologies of these models have recently been suggested (Crompton 1999, Haas 2005).

The dual-earner/dual-carer model, in the version in which both partners share the household chores equally, is advocated as the preferred model for the balance of work and parenthood (Gornick and Meyers, 2003), particularly in countries with a social democratic type of welfare regime, and where public child care is widely available (Rønsen and Skrede 2008). The strength of this model is two-fold. On the one hand, it ensures a gender-egalitarian, gender-symmetrical distribution of labor and responsibilities in the family. On the other hand, from the child's perspective, it ensures that both parents spend time with their child (or children). The model is considered as optimal both in cases where the woman is engaged in full-time paid work, and when her engagement is part-time.

Hence, the dual-earner/dual-carer model of distribution of labor in the family is superior to other models with respect to childrearing, and it may be expected that, following the question of this debate, European governments should aggressively support the transition to this model.

\section{Empirical observations}

Before discussing these models further, it is helpful to consider some empirical illustrations. Table 1 gives the average number of hours worked per week in the household, as reported by women below age 40 who reside with a partner in a nonmarital partnership. Since time spent on child care depends on the number of children, it is excluded in the estimation in order to achieve higher comparability across countries. 
Table 1: Weekly hours spent on household work (mean); responses of females below age 40 with a steady non-marital partner; time spent on child care not included

\begin{tabular}{lccc}
\hline & Females & Males & Female/Male \\
\hline Austria & 16 & 6 & 2.7 \\
France & 7 & 4 & 1.8 \\
Germany-West & 11 & 6 & 1.8 \\
Germany-East & 11 & 5 & 2.2 \\
Great Britain & 8 & 4 & 2.0 \\
Netherlands & 11 & 5 & 2.2 \\
Sweden & 10 & 6 & 1.7 \\
Spain & 14 & 7 & 2.0 \\
Hungary & 20 & 7 & 2.9 \\
Poland & 20 & 11 & 1.8 \\
Bulgaria & 13 & 7 & 1.9 \\
Russia & 23 & 12 & 1.9 \\
\hline
\end{tabular}

Source: International Social Survey Programme, 2002

I intentionally chose only non-married partners. These partnerships are considered to be a modern counterpart of traditional marriage that gives women more autonomy. Were married partners included, the females' shares would be higher.

The table shows that, in all countries where the question has been asked, women report spending about twice as much time on household work as their partners (in Austria and Hungary, nearly three times as much). Whatever the employment status of the two partners, there is little reason to assume that the dual-carer model in its symmetric version is dominant in any one of the countries included in the table. The table also shows that the women's burden is particularly heavy with respect to the length of time devoted to household work in some countries, like Hungary, Poland, and Russia, where women spend around 20 hours on work in the household that does not include child care. This is half of a full-time working week.

Table 2 gives similar information from another survey. The percentages of the responses "both in equal shares" define the proportion of the dual-carer model. Again, the female-carer model prevails in all five countries included in the table. The empirical data presented in this table are based on household work that did not include child care; were the latter included, the "equal shares" percentage would fall. 
Table 2: Responses of females aged 20 to 40 to the question: "Who usually does the household work?" in percent

\begin{tabular}{lccccc}
\hline & Mostly I do & Mostly partner & Both in equal shares & Others & Total \\
\hline Austria & 73 & 4 & 22 & 2 & 100 \\
Estonia & 56 & 1 & 43 & 1 & 100 \\
Hungary & 73 & 2 & 24 & 2 & 100 \\
Lithuania & 62 & 2 & 34 & 2 & 100 \\
Romania & 51 & 5 & 37 & 7 & 100 \\
\hline
\end{tabular}

Source: BIB (2002)

Both tables indicate that, at the macro-level of the whole population, the division of household labor between the two partners is favorable for the men, who do a smaller share of the work.

Both datasets were further disaggregated by the employment status of the woman (regrettably, this led to a very small number of observations in some cases). Three statuses were considered: not in work, full-time employment, and part-time employment. The results indicated that men allocate slightly more time for household work when their partners work, regardless of whether the woman's employment is fulltime or part-time. This relative increase of men's involvement in household work does not change the corresponding type of the model; the woman's share remains high compared to the man's in every one of the three cases.

This brief empirical review indicates that the woman-carer model is dominant in Europe, including in the cases where the woman works. Gender inequality prevails in Europe when division of labor in the family is considered, and the "best" dualearner/dual-carer model is not dominant anywhere in Europe.

Hence, if governments in Europe aim to aggressively stimulate a transition to the dual-earner/dual-carer model with the goal of increasing fertility, they should make sure that the transition encompasses within a short time period a large part of the population who at present are classified under the male breadwinner model, or the dualearner/woman-carer model.

\section{Objections}

I raise objections to the view that the sizeable propagation of the dual-earner/dual-carer model will lead to a sizeable increase in fertility in a short time period (such as several years). For this purpose, I first consider the negative and the positive sides of each model from the point-of-view of childrearing. 
A. The traditional male breadwinner model has the following positive sides:

- Better division of labor in the family. The woman is specialized in household work and can do it better than the man; the man takes care of the family income, and thus the woman and man support each other (Becker 1991).

- Higher-quality childrearing. It is achieved because the woman stays at home and is able to devote more time to her children. From the societal point-of-view, childrearing is an investment in the creation of citizens with greater knowledge, abilities, and cognition.

The negative sides include:

- Lower female autonomy and self-expression through labor (however, it can be argued that the latter is replaced by self-expression through home care and childrearing). Women who stay at home may have fewer social contacts.

- Lower family income

B. Dual-earner/dual-carer model

The positive and negative sides are the inverse of the previous model. The positive sides include:

- Achievement of higher female autonomy, higher self-expression of women

- Wider social contacts at the place of work

- Higher family income

The negative sides are:

- No division of labor, and, hence, lower quality of household work

- Least amount of parental time for childrearing

- Opportunity costs of childrearing can be high (Becker 1991)

C. The dual-earner/dual-carer with a part-time work involvement for women is a model that is intermediate between models A and B. When compared with model A, its positive and negative sides are the same as for model B, with a difference in the intensity in their manifestations. For example, family income will be higher (but hardly high enough in order to satisfy the greater needs of the family that may be expected following the birth of a child). When compared with model $\mathrm{B}$, the positive sides include more time for maternal care, and a lower effect of opportunity costs; while the negative sides include restricted opportunities for autonomy and self-expression of women, and lower family income. 
The main premise in this paper is that governments will seek to aggressively change the breadwinner model so that fertility will increase. Consider first a stimulated change from model (A) to model (B). The positive aspects of model (B) will then be expected to contribute to a rise in fertility. Is that to be expected?

- Achievement of female autonomy, self-expression, and career orientation: these values are central in the theoretical discussion about the effect on fertility of ideational changes that have occurred over the last couple of decades. They have been considered among the causes of lower fertility (Lesthaeghe 1995). This positive side for the policy target is expected to have a negative effect on fertility.

- Increase in family income through labor participation of women: Is the direct income effect or the effect of opportunity costs stronger? We do not have sufficient knowledge to determine which effect prevails, and whether the net effect is high enough to push women towards the decision to have a child.

Consider a stimulated change from model (A) to model (C). Will part-time involvement in labor be satisfactory for the achievement of personal autonomy and selfrealization? Hardly. Working part-time provides considerably fewer opportunities to pursue a career in a competitive labor market in which others work full-time. In this respect, the research reported in the book edited by Blossfeld and Hakim (1997) is indicative. The title of the book suggests that part-time work can lead to a marginalization of women on the labor market. Thus the model may lead to specific disadvantages for the women.

This short overview of the models leads to the following objections:

Objection 1: There is no perfect model for the division of labor in the family that would promote greater gender equality in such a way that fertility would increase. Governments do not have a clear mandate to push aggressively for gender equality in order to increase fertility.

The following observation must be made. Gender policies designed to promote the transition to gender equality will benefit from some instruments associated with family policies. The introduction of parental leave is an example of such an instrument. As discussed in the first section, gender policies and family policies intersect in the models for the division of labor. However, the positive effect of similar instruments of family policies on fertility should not be assigned to gender equality policies.

Suppose gender-related policies are implemented with the purpose of enforcing one specific model of the division of labor, even though this model is not really advantageous. Suppose the implementation is done in an aggressive way, as the title states. This sudden change in societal life will have significant macro-economic 
consequences. As an example, suppose that the policies aim at a decrease in full-time work among women (and/or among men) and its replacement with part-time work. Labor supply will swiftly decline, with all the negative consequences for the labor market and the economy. Inversely, if women are given policy-assured advantages for work, they may wish to change their labor status by moving towards a longer time allocation for labor. In the latter case, there will be a swift rise in the supply of labor with the macro-level consequences that wages will decrease or unemployment will increase. These considerations lead to the next objection.

Objection 2: An aggressive introduction of policies aiming at achieving gender equality in order to increase fertility will lead to an imbalance between the supply and demand for labor in the labor market.

The next topic refers to the biological and genetic differences between the two sexes. Gender equality is not full symmetry between the two genders because of these differences (excluding differences in physical power). What matters for our discussion is the hormonal difference, which has a primary importance for the development of body and brain structures. Hormones guide the behavior of the individuals and reproductive behavior in particular (Udry 1994, 1996).

Hormones cause sex-differentiated brain structures and behavior. The latter make up the foundation of social norms related to gender. Gender norms can therefore be the consequence of biological differences. As Udry (1994: p 563) states, “...the behaviors related most closely to reproduction and infant survival are the most sex-dimorphic. In humans these behaviors form the foundation for the division of labor by sex."

This statement indicates that policies aiming at gender equality in order to increase fertility cannot disregard the biological differences between the sexes. Gender equality is not "sameness;" there are gender differences defined by biology and genetics. There are therefore gender norms that have a biological basis. The policies we discuss here must therefore either account for this specific gender difference, or be effective against the impact of biology and genetics. We do not have the relevant knowledge for the design of such policies.

One genetic aspect related to gender equality in the framework of our argument is analyzed by Foster (2000). Motherhood and nurturing are in the genes, and individuals have a genetic predisposition towards the relevant behavior. The sex dimorphism is clear-cut: the word is about motherhood, not about fatherhood. Gender roles with respect to parenthood and nurturing cannot be symmetric because of genetic differences between the sexes. Again, a policy that aims to achieve symmetry between motherhood and fatherhood must be able to successfully compete with the genetic predisposition of human beings. We do not have sufficient relevant knowledge for the design of such a policy. 
In fact, the inverse problem can be put forward: Didn't an over-gendered human nature suppress the genetic predisposition to motherhood? Meaning, is it possible that the pursuit of gender equality has gone too far, and has turned into a reason for low fertility?

These views have been expressed explicitly with respect to gender equality in the "theory of differences" (Irigaray 1991). As a feminist theory, it emphasizes the special and unique position of women as mothers which should not be subject to women's "liberation."

Objection 3: Governments' aggressive push towards gender equality in order to increase fertility will hit up against innate gender differences that policies will not be able to overcome.

The next topic refers to the following part of the central question: "governments in Europe." The question here is whether the policies targeting gender equality with the goal of increasing births should be similar in the different European countries, or whether these policies need to be country-specific.

Figure 1 shows the responses of men and women to a question designed for the measurement of a specific gender aspect: the ultimate role of women in society (work for pay versus home care and child care). The figure shows an enormous diversity among respondents in eight countries in their views about the ultimate role of women. While in the Netherlands neither men nor women support the ultimate role being that of a homemaker (around 15\% agree with the question), in Hungary precisely the inverse is observed. The figure also shows that the Central Eastern European countries are clearly separated from the Central Western countries with respect to this gender-related value.

The data indicate a significant diversity in Europe with respect to gender norms and values. Hence the application of one country's policy approach to another country could bring about an ineffective policy construction. The policies related to gender equality need to be country-specific. Every country needs specific background information on gender issues.

Objection 4: Governments in Europe should not use one and the same policy approach to achieve gender equality; there is no transnational policy. Governments need country-specific research as a basis for their policies. This basis is hardly available in most of the European countries.

Last but not least is the topic related to cultural aspects of gender equality and motherhood. Apparently the traditional male breadwinner model has been dominant in European societies, and it is woven into societal norms and personal values. A transition to a different model of the gender division of labor in the family requires an accompanying transition in these norms and values. Ideational changes have been said 
to be on the way. Indeed, individualization and the desire to achieve personal autonomy and fulfillment through labor is gaining ground in nearly the whole of Europe (Lestheaghe 1995). However, traditional values around motherhood maintain their dominance. Thus motherhood is also a path to fulfillment; and, for mothers, it is rewarding to care for their children. Cultural models of work and family are frequently discussed in the literature, and it is widely recognized that gender equality has to be understood within the cultural environment (Blair-Loy and Frenkel 2005, Hays 1996, Pfau-Effinger 2006).

Objection 5: Policies aiming to achieve gender equality should be consistent with the cultural environment; the cultural environment changes slowly and hence retards actual policy performance, particularly when the policies are introduced aggressively.

Figure 1: Respondents aged 20 to 40 , in \%, who agree with the statement: "Work is good but what most women really want is a home and children"

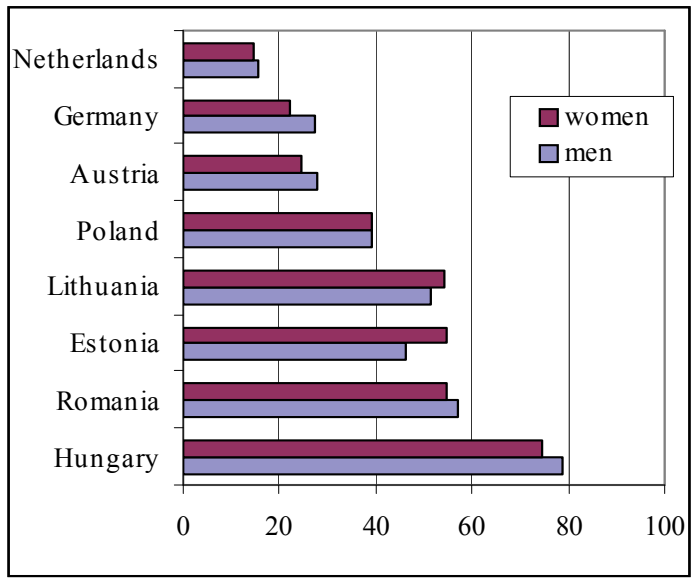

Source: BIB (2002) 


\section{Summary and conclusions}

The transition from a male breadwinner model of the division of labor in the household to a model with a more gender-equal division of labor is a tendency observed in many European societies. Gender equality is a highly appreciated value in contemporary democratic societies, and is supported by governmental bodies and the European Union through the idea of gender mainstreaming. To this end, progress towards the achievement of "a new gender contract" that closely links work, welfare, and family (Esping-Andersen 2002) is occurring steadily in European societies, and it will continue regardless of the impact on fertility.

This paper discusses the suggestion that efforts to achieve gender equality be extended in order to increase fertility, and that governments should design relevant policies, and should implement them in an aggressive manner. I raised five objections to this suggestion, which is a bare minimum. The objections can be summarized with in one general observation; namely, that an extension of policies aiming to achieve gender equality in order to increase fertility is not based on sound research. The aim of such a policy - for example, the achievement of a dual-earner/dual-carer model—will not necessarily lead to a higher fertility; moreover the aggressiveness in policy implementation will hit up against slower changes in values and norms, and will result in an imbalance in the supply and demand for labor.

Governments follow another path that unites the pursuit of gender equality and an increase in fertility. To achieve these ends, they can apply policies that promote gender equality and family formation (including contemporary pronatalist policies). These two policies intersect in the models for division of household labor. Both can support the dual-earner/dual-carer model or its variants, with relevant policy instruments. However, the policy instruments that can be placed at the intersection point should be carefully classified. To this end, both policies should consider the importance of the principle of neutrality. Thus, gender neutrality is a basic principle in the construction of policies intended to increase the number of births (McDonald 2006). Analogously, policies that seek to achieve gender equality should be neutral with respect to fertility change. The compatibility of the two policies is clear, and when they both enforce their intersection point, the dual-earner/dual-carer model, fertility is likely to increase, at least in the long run. 


\section{References}

Andersson, G. (2008). A review of policies and practices related to the 'highest-low' fertility of Sweden. Vienna Yearbook of Population Research 2008: 89-102. (Vienna Institute of Demography). doi:10.1553/populationyearbook2008s89.

Becker, G. (1991). A Treatise on the Family. Harvard University Press.

BIB (2002). The Demographic Future of Europe - Facts, Figures, Policies. (Brochure). http://www.bib-demographie.de/ppa/Main.htm.

Björklund, A. (2006). Does family policy affect fertility? Lessons from Sweden. Journal of Population Economics 19(1): 3-24. doi:10.1007/s00148-005-0024-0.

Blair-Loy, M. and Frenkel, M. (2005). Societal Cultural Models of Work and Family: An International Perspective. In: Pitt-Catsouphes, M. and Raskin, P. (eds.). Work-Family Encyclopedia. Chestnut Hill, MA: Sloan Work and Family Research Network at Boston College. http://wfnetwork.bc. edu/encyclopedia_template.php?id=1960.

Blossfeld, H.-P. and Drobnic, S. (eds.) (2001). Careers of Couples in Contemporary Society: From Male Breadwinner to Dual-Earner Families. Oxford University Press.

Blossfeld H.-P. and Hakim, C. (1997). Between equalization and marginalization. Part-time working women in Europe and the United States of America, Oxford: Oxford University Press.

Büttner, T. and Lutz, W. (1990). Estimating fertility responses to policy measures in the German Democratic Republic. Population and Development Review 16(3): 539555. doi:10.2307/1972835.

Council of Europe (1998). Gender mainstreaming. Conceptual framework, methodology and presentation of good practices. Final report of Activities of the Group of Specialists on Mainstreaming. Strasbourg. (EG-S-MS (1998) 2).

Crompton, R. (ed.) (1999). Restructuring Gender Relations and Employment: The Decline of the Male Breadwinner. Oxford: Oxford University Press.

Debroy, B. (1989). Fertility trends and population policies and programmes in Socialist Europe. Social Scientist 17(7-8): 66-87. doi:10.2307/3517287.

Esping-Andersen, G. (2002). A New Gender Contract. In: Esping-Andersen, G., Hemerijck, A., and Myles, J. (eds.). Why we need a New Welfare State. Oxford University Press. 
Foster, C. (2000). The limits to low fertility: A biosocial approach. Population and Development Review 26(2): 209-234. doi:10.1111/j.1728-4457.2000.00209.x.

Gauthier, A.-H. and Hatzius, J. (1997). Family benefits and fertility: An econometric analysis. Population Studies 51(3): 295-306. doi:10.1080/ 0032472031000150066.

Gauthier, A.-H. (2007). The impact of family policies on fertility in industrialized countries: A review of the literature. Population Research and Policy Review, 26(3), 323346. doi:10.1007/s11113-007-9033-x

Gauthier, A.-H. and Philipov, D. (2008). Can policies enhance fertility in Europe? Vienna Yearbook of Population Research 2008: 1-16. (Vienna Institute of Demography). doi:10.1553/populationyearbook2008s1.

Gornick, J.C. and Meyers, M. (2003). Families that work (Policies for reconciling parenthood and employment). New York: Russell Sage Foundation.

Haas, B. (2005). The Work-Care Balance: Is it possible to identify typologies for crossnational comparisons? Current Sociology 53(3): 487-508. doi:10.1177/0011392105051337.

Hays, S. (1996). The cultural contradictions of motherhood. New Haven: Yale University Press.

Irigaray, L. (1991). Ethik der sexuellen Differenz. Frankfurt am Main: Suhrkamp.

Lesthaeghe, R. (1995). The second demographic transition in western countries: An interpretation. In: Oppenheim-Mason, K. and Jensen, A.-M. (eds.). Gender and Family Change in Industrialised Countries. Oxford: Clarendon Press.

Lewis, J. (1992). Gender and the development of welfare regimes. Journal of European Social Policy 2(3): 159-173. doi:10.1177/095892879200200301.

Lewis, J. (2001). The decline of the male breadwinner model: Implications for work and care. Social Politics 8(2): 152-169.

McDonald, P. (2006). An assessment of policies that support having children from the perspectives of equity, efficiency and efficacy. Vienna Yearbook for Population Research 2006: 213-234. (Vienna Institute for Demography). doi:10.1553/populationyearbook2006s213.

Pailhé, A., Rossier, C., and Toulemon, L. (2008). French family policy: Long tradition and diversified measures. Vienna Yearbook of Population Research: 149-164. (Vienna Institute of Demography). doi:10.1553/populationyearbook2008s 149. 
Pascal, G. and Lewis, J. (2004). Emerging gender regimes and policies for gender equality in a wider Europe. Journal of Social Policy 33(3): 373-394. doi:10.1017/S004727940400772X.

Pfau-Effinger, B. (2006). Cultures of childhood and the relationship of care and employment in European welfare states. In: Lewis, J. (ed.). Children, Changing Families and Welfare States. Cheltenham UK, Northampton MA, USA: Edward Elgar: 137-153.

Philipov, D. (1993). Period-cohort analysis of the effectiveness of the demographic policy. Statistika 2: 40-51. (Sofia: National Statistical Institute).

Rønsen, M. and Skrede, K. (2008). Fertility trends and differentials in the Nordic countries - Footprints of welfare policies and challenges on the road ahead. Vienna Yearbook of Population Research 2008: 103-123. (Vienna Institute of Demography). doi:10.1553/populationyearbook2008s103.

Stloukal, L. (1998). An APC analysis of demographic responses to population policy measures: The case of the Czech and the Slovak Republics 1960-1990. Genus 54: 87-121.

Udry, J.R. (1994). The nature of gender. Demography 31(4): 561-573. doi:10.2307/2061790.

Udry, J.R. (1996). Biosocial models of low-fertility societies. Population and Development Review. Supplement: Fertility in the United States: New Patterns, New Theories 22: 325-336. doi:10.2307/2808017. 